\title{
TRAVEL TO THE HEALING CENTERS IN THE EGYPTIAN TEMPLES: THE PROTOTYPE OF THE MODERN MEDICAL TOURISM
}

\author{
Abouelata, M. \\ College of Tourism and Archaeology, King Saud Univ., KSA \\ Egyptology dept., Faculty of Archaeology, Fayoum Univ., Egypt \\ E-mail:abolattaa@yahoo.com
}

\begin{abstract}
A travel for treatment was one of the oldest motivations for travel in ancient world. Among the sites that attracted such travelers were the supposed healing centers in Egyptian temples. As the ancient Egyptian physicians were very clever in their profession, they had a very remarkable fame not only in Egypt but among the patients of other ancient nations as well. The ancient Egyptian and foreigner patients traveled to those medical centers to spend a night or more seeking for cure by medical treatment or through dreams and messages from gods. The architectural evidences prove the existence of such healing centers in the temples. The only preserved example is the sanatorium within the precinct of the Hathor temple at Dendera, in Upper Egypt. According to the modern concept of tourism, such travels were more or less a type of tourism. In this context, this paper, through the textual, pictorial, and architectural evidences, tries to originate the earlier examples of medical tourism, as well as it applies the concept and components of present tourism on the travels of ancient Egyptian and foreigner patients.
\end{abstract}

Keywords: Medical tourism, Ancient Egypt, Egyptian temples, Egyptian medicine

\section{Introduction}

In ancient Egypt, the patients travelled to certain destination for obtaining health care. This practice might have been very ancient, as medicine was known in ancient Egypt since very early beginning. Manetho, an Egyptian historian during the third century BC, mentioned that Athothis "Djer", the third pharaoh of the first dynasty during the fourth millennium BC, was a talented physician [1]. The practice of medicine in ancient Egypt developed through time to the extent that the Egyptian doctors had a great fame in and abroad Egypt as well [2]. It was one of the advanced practices astonished the Greek writers and travelers. Homer mentioned
Egypt in the Odyssey as a land "where fertile soil produces the greatest share of medicine, many good in mixture, but also many harmful, and every man there is a physician and knows more than men elsewhere" [3]. Herodotus was fascinated by the high level of specialization of the Egyptian physicians. $\mathrm{He}$ mentioned, "Medicine with them is divided so that everyone is a physician for one disease and not for more diseases. Physicians are everywhere there. Some are eye doctors, others heal the head, others teeth, and still others the stomach and others invisible diseases" [4]. Although the long history of Egyptian medicine, its great 
development and the good fame of its participant, it is not obviously known where exactly the Egyptian physicians taught and practiced their skills in medicine. The most suggested place is the temple or exactly

\section{The Textual Evidences}

Searching the textual evidences tries to root four points; the existence of house of life in temple, the connection between house of life and medicine, temples as medical centers, and the patients' travel to those medical center. As for the existence of house of life in temple, there are many evidences on such existence in various Egyptian temples. In Bubastis, in Eastern Delta, an inscription on the discovered door of Irwy of the twentieth dynasty mentioned the offering presented by the king to Atum lord of house of life. It also describes Irwy as chief priest of Sekhmet [5]. The connection between medicine and priesthood of Sekhmet is obvious through the texts of medical papyri [6]. Another evidence of existence of medical education center in Bubastis is the statue of the chief priest of Sekhmet in Bubastis, son of the chief physician Amenhotep [5]. In Sais, in Western Delta, Udjahorresnet, the chief physician and the chief priest of goddess Neith of Sais during the Persian rule, left a long text on his naophorous statue mention the instruction given to him by the Persian king Darius to restore the house of life in Sais [7]. He recorded that he supplied the house of life with students, teachers, and tools in order to heal every patient. He mentioned that Darius ordered that as he respects the value of that medical art [8]. In Abydos, in Upper Egypt, the overseer of the Neith temple, the chief physician Peftjawaneith, of the twenty-sixth dynasty, recorded on his statue - preserved now in the Louvre that he restored the house of life after it has collapsed [9]. It should be recognized through the restoration texts of Udjahorresnet and Peftjawaneith that they both physicians and, in the same time, priests of Neith. These restoration works, done by priests, the house of life attached to it. Some of these Egyptian temples were destinations for patients who traveled there seeking for medical care.

obviously indicate the existence of such medical educational centers in temples, with their own system, since earlier times. The author of Ebers medical papyrus mentioned the gods of Heliopolis together with the gods of Sais, how they gave him their protection and taught him to cure the diseases of every sort [10]. The author of Hearst papyrus confirmed the same meaning [11]. These authors refer to the wisdom that they gained through these gods, the matter that could ensure the existence of a medical education center attached to the temple of Atum in Heliopolis in Lower Egypt. All these textual evidences certify the existence of houses of life in many Egyptian temples. These houses of life were, in somehow, connected to teaching or practicing medicine. Although, there was no specific school for teaching medicine, it was most probably, like other knowledge, attached to temples. It was in the houses of life where a likely particular section for teaching medicine exists. The connection between house of life and medicine could be certified through various allusions that include: Many physicians had some titles related to the house of life. Niankhre, the physician in the fifth dynasty was the chief in the house of life [12]. Aha, the chief scribe in the house of life was in the same time the chief of the myrrh house [13], the myrrh was used in medicine and mentioned a lot in many medical prescriptions [2]. The physician Menna, of the eighteenth dynasty, had the title "the chief physician in the house of life" [14]. This is an obvious evidence for the relation between the house of life and medicine. In the ruins of the house of life of the city of Akhetaten, some medical instruments were found [15]. This indicates that the 
building used for some medical purposes. When Bentresh, sister of Neferure wife of Ramsses II, was sick, a messenger came to Egypt asking for a medical assistance to cure the princess. The pharaoh sent one of the scientists in the house of life to help in that [16]. These allusions lead to suggest that the houses of life attached to the Egyptian temples had some medical functions and offered cure services. Although there are no clear evidences that temples were used as medical centers, there are some indications that they were. One evidence is the existence of houses of life attached to the temples, except for Amarna where it was separated. These houses of life functioned as educational centers for teaching medicine. Another evidence is the discovery of some medical papyri in temples vicinity such as the Ramesseum papyri, which found in a wooden box at the bottom of a shaft under the brick magazine behind the great temple of Ramesseum temple [1]. Moreover, the titles of the temple physicians; the physician Pahatyu, of the New Kingdom, had the title of "the overseer of the physicians in the temple of Amon". Another physician of nineteenth dynasty, Amenhotep, had the title of "chief physician in the temple of Amon" [17]. Innay, of the twentieth dynasty, had the title of "overseer of doctors in the temple of Ptah" [18]. Nakhtsaes, of the Late Period, was a physician and "the over secretary health in the temple of Thot", this last title indicates that this position was a matter of skill and knowledge and not of magic [19]. The text of Udjahorresnet in which he mentioned supplying the house of life with tools in order to heal every patient is a considerable reference to practicing medicine in the house of life in the temple of Neith in Sais. Concerning the patients' travel to that supposed healing centers in Egyptian temples, there are some textual evidences left by these patients on the walls of these temples. Along the walls of a small cave high above the temple of Hatshepsut at Deir el-Bahari, several New Kingdom hieratic graffiti are penned. Text of Nebwa, a priest and scribe of the memorial temple of Tuthmosis I, mentioned, "He came to be cured completely" that leads to suggest the existence of a sanatorium at Deir elBahari in the New Kingdom [20,21]. Although the text might be misinterpreted and the right reading could be "he came to see this place and to enjoy himself in it" or "to have a good time" [22]. What pleasure there was to be had in this remote eyrie other than some peace and quiet is not clear. Nebwa may have stumbled into it when visiting the Deir el-Bahari temples and he seized the opportunity for some cool shade, perhaps he utilized it as drinking den or the like [23]. An interesting story has survived which illustrates a visit to practice incubation at the temple of Imhotep, the Egyptian god of medicine. The story relates to a man named Satmi Khamuas, the son of the Pharaoh Usermares, who had no man-child by his wife Mahftuaskhit; this afflicted him greatly in his heart, and his wife was greatly afflicted with him. One day, when he was more depressed than usual, his wife Mahituaskhit went to the temple of Imhotep, son of Ptah, and prayed before him. She asked him to turn his face towards her, to listen to her lamentation and give her conception of a man-child. After that, she slept in the temple and had a dream that same night. A sound advised her after finishing sleep in the temple to receive a remedy for sterility from the hands of the god, to go to the bathroom of her husband and take the leaves of colocasia growing there to make a remedy and give it to her husband, then to lie by his side. The sound promised her that she would conceive by him the same night [24]. When Mahituaskhit awoke from her dream she did everything according to that which had been; then she lay by the side of Satmi, her husband, and she conceived by him. When the time came, she had the signs of pregnant women, and Satmi announced it to Pharaoh, for his heart rejoiced greatly; he bound an amulet upon her and recited a spell over her. Eventually she gave birth to a remarkable boy named Senosiris, who later on 
performed many wonders in the land of Egypt [24]. A similar story of sterility being cured by Imhotep is told in a famous stele of the Ptolemaic Period, now in the British Museum. The story relates to a woman named Thet-Imhotep. She was born in the ninth year of the reign of Ptolemy XIII, when fourteen years old she was married to her half-brother, the priest P-Shere-enPtah. During the first twelve years of her married life, she gave birth to three daughters, but had no son, which caused her husband great grief. She and her husband prayed to the god Imhotep, the son of Ptah, for a son; in response, the god, appearing to P-Shere-en-Ptah in a dream, promised to grant his prayer if he carried out certain works in connection with the temple. When the priest awoke, he caused the works to be taken in hand, and soon after they were completed, his wife gave birth to a son who was named Imhotep, and surnamed Pedi-Bast [24]. On the other hand, the travel of Egyptian physicians, also referred to as "learned men" or "knower of things", to the foreign patients in their homelands is known from textual sources dating from the later eighteenth dynasty into the Late Period [25]. Foreign kings and princes often requested Egyptian physicians; sometimes they were sent to foreign countries by the Egyptian kings [26]. For example, the prince at Ugarit requested from Akhenaten several palace attendants, including one who was a physician, because there was none at Ugarit [27]. From Akkadian records, it is known that the practice of sending Egyptian doctors to Hatti was a regular occurrence during the reign of Ramesses II. Indeed, the physician Paraemhat traveled more than one occasion to Hatti to aid both Hattusilis III at the Hittite court and his vassals [28]. The Late Period Bentresh stela, although fictitious, also reflect the historical reality of the physicians exch-

\section{The Pictorial evidences}

There are some pictorial evidences prove the patients' travel to the Egyptian physicians' centers. There are two scenes anges between Ramesses II and the Near Eastern kings. It details the prince of Bakhtan's request for a "learned man" to aid his sister and the subsequent sending of Djhutyemhab from the house of life to Naharin [16,29]. In addition, the Late Period inscription of the chief physician Udjahorresnet mentioned that he was "made" a physician by Cambyses, living with the king at the palace, and was later sent back to Egypt by Darius to "restore the house of life" [25,30]. Such travel of the Egyptian physicians to the patients in foreign lands indicates that there was a contrast travel to the Egyptian physicians in their homeland practiced by the foreign patients, who were not members in royal families, had no ability to ask the pharaoh to send them an Egyptian physician. They most probably traveled to Egypt asking for cure on the hands of the well-known Egyptian doctors. Such suggestion could be confirmed by the scene represents Syrians in the presence of the Egyptian physician Nebamun. Another textual evidence, but later in date, is the inscription of a Greek patient in Deir el Bahari, in which he mentioned that he was sick, thus he came to visit Imhotep, the Egyptian equivalent of the Greek medicine good Asclepius, asking him for good health and he became completely cured [21]. Although the rear evidences of using temples as medical centers in Pharaonic Egypt, it was known in the Ptolemaic Period that the temples at Denderah, Memphis, and Deir el-Bahari were notable for their treatment of the sick and especially for the cure of the mentally and emotionally disturbed. The treatment offered there may in fact have been practiced in Egypt at earlier periods [31] and they attracted visitors from everywhere.

on the rear wall of the transverse hall of the New Kingdom tomb of Nebamun in Thebes (TT17) [32]. These two scenes are 
immediately visible to an external viewer looking into the tomb, as well as the visitor who is just entering the tomb. Scenes in such place are usually interpreted as containing the most distinguish information that presents the tomb owner to his viewers [33]. The first scene is on the northern half of the wall [32]. It shows Nebamun seated and receiving offerings from his brother Sheni with two registers of Syrians behind him, including a depiction of a Syrian dignitary, and his wife, being offered a drink, fig. (1), a ship, and more foreigners leading bullsare shown. Nebamun holds the staff and scepter of office, with a scribal case and palette beneath his chair. The scene depicts Nebamun in his official capacity, and the Syrians in the scene relate to one face of Nebamun's duties [34]. This scene had different interpretation by scholars, some connected it with the function of ancient Egyptian physicians [1,25] and others considered it as evidence for Egyptian doctors in foreign lands [35]. Although the presence of Egyptian physicians in foreign countries is known from textual sources, and despite the lack of identification text of this scene, its details lead to believe that the event depicted took place in Egypt [34], these details include: The Syrian objects and costumes depicted in parallel scenes in the New Kingdom Theban tombs[36,37]. The Egyptian jar stands that belonging to a style known since the Middle Kingdom [38]. The stool on which the Syrian seated is an Egyptian "round-legged" stool that developed during the eighteenth dynasty out of an earlier Middle Kingdom style [38]. The Syrian dignitary holds a bolt of cloth that is a purely Egyptian marker of status [39]. The total absence of the foreign environment in the whole scenes of the tomb like what appeared in other tombs $[36,40]$. The focal point of the scene itself, where an Egyptian figure serves the seated Syrian, it seems unlikely that an Egyptian would be serving a Syrian in his own court [34]. Above the seated figure of Nebamun, he was called "scribe, chief physician of the king in Thebes". The title that found in at least three inscriptions in his tomb. The mention of Thebes in the title used in this scene indicates that Thebes was more likely the place of event [34]. The position of depiction the Syrian ships, comparing to other few Syrian ships scenes in Theban tombs that always representing the arrival of these ships to an Egyptian port [41], proves that the scene here representing ships departing from Syria [34]. Through these details, the scene could be read as a representation of Syrians departure from their homeland, and their presence in Egypt. Thebes, as the place of Nebamun meeting with Syrians, is concluded through his own title of physician of the king in Thebes, and by parallels with other officials and their tombs. Thebes during the mid-eighteenth dynasty was a city of great importance, a place to find foreign emissaries as well as visitors. Cuneiform documents indicate that foreigners of that period recognized the importance of Thebes $[42,43]$. Why did these Syrians come to Thebes and why was Nebamun present? It should be some act related to his position as chief physician of the king in Thebes as he acted in the scene in his capacity as a royal physician. It could be said that the scene depicts a private visit by a Syrian dignitary to the royal physician in Thebes. The lack of identification could perhaps indicate that visits from Syrian dignitaries were a recurring part of Nebamun's career as a royal physician in Thebes [34]. The fact that Nebamun chose to depict two particular aspects of the Syrians' journey, namely the original departure by ship from Syria and his subsequent interaction with them in Thebes at a banquet, suggests that these two episodes were of great personal significance to him. Taken together, they lend support to the theory that the Syrian dignitary came to Thebes at least in part to consult the royal physician, and that the items carried by the Syrians were perhaps intended as gifts for Nebamun in exchange for his professional services [25]. The second scene 
is on the south side of the rear wall [32]. It shows Nebamun stands holding a staff and watching four registers of activities that include grain storage, baking, brewing and grinding. The inscription above Nebamun indicate that he is inspecting goods in Upper Egypt in his capacity as scribe and physician of the king in Thebes. This indicates that he is engaged in a work related to his position as physician [34]. This scene could be compared with another Theban scene of the Ramesside tomb of Ibwy at Deir el-Medina (TT217) [44], which is suggested to displays a satire on workplace injuries [1], and viewed as the only tomb depiction of a physician at work [45]. It could also be linked with the probability that most physicians made their own medicines, and the physician Iwty, during the reign of Ramesses I, seems to have had his own workshop or pharmacy for this purpose $[25,45]$. Perhaps then, Nebamun's scene depicts just such a physician's workshop, with the granaries connected to it depicted in the upper registers, while the staff, activities, and presentation of results for inspection in the lower registers. The fact that Nebamun chose to refer to himself in this scene as the physician of the king in Thebes also suggests that this workshop existed somewhere in Thebes or the nearby vicinity [34]. Nebamun chose two scenes as focal points of his tomb. The scene on the north side evokes the visits of Syrian dignitaries and their entourage who traveled to Thebes and Nebamun's interaction with them in his role as chief physician in Thebes. The scene on the south side depicts an equally significant, making of medicines and inspection of his physician's workshop, again as the physician of the king in Thebes [34]. As the only New Kingdom tomb of a physician whose scenes actually depict aspects of his career, Nebamun's tomb (TT17) becomes an important source of information about the role and duties of the New Kingdom physicians and the only pictorial source that confirms the travel of foreigner patients to Egypt hoping for medical treatment. Another pictorial evidence is the scene of medical instruments depicted on the inner of enclosure wall of the temple of KomOmbo, fig. (2). Although later in times than the Dynastic Periods and does not really represent the Pharaonic instruments [1], it could be regarded as an evidence that these instruments were in use in the temple precinct or at least in its vicinity, which lead to suppose that some other earlier temples had similarinstruments.

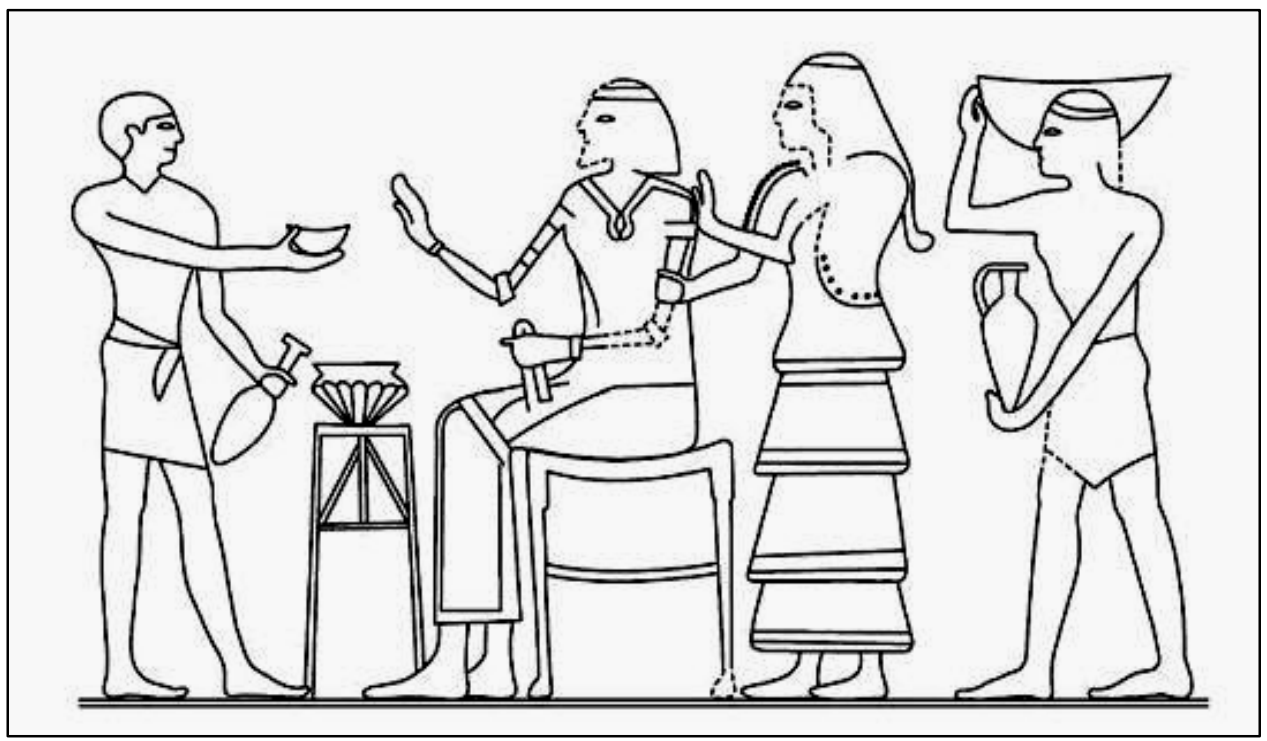

Figure (1) Shows details from the scene of Nebamun's tomb shows Syrian dignitary being given a medicine (after Strouhal, Vachala, and Vymazalova, The Medicine of the Ancient Egyptians, Fig. 2) 


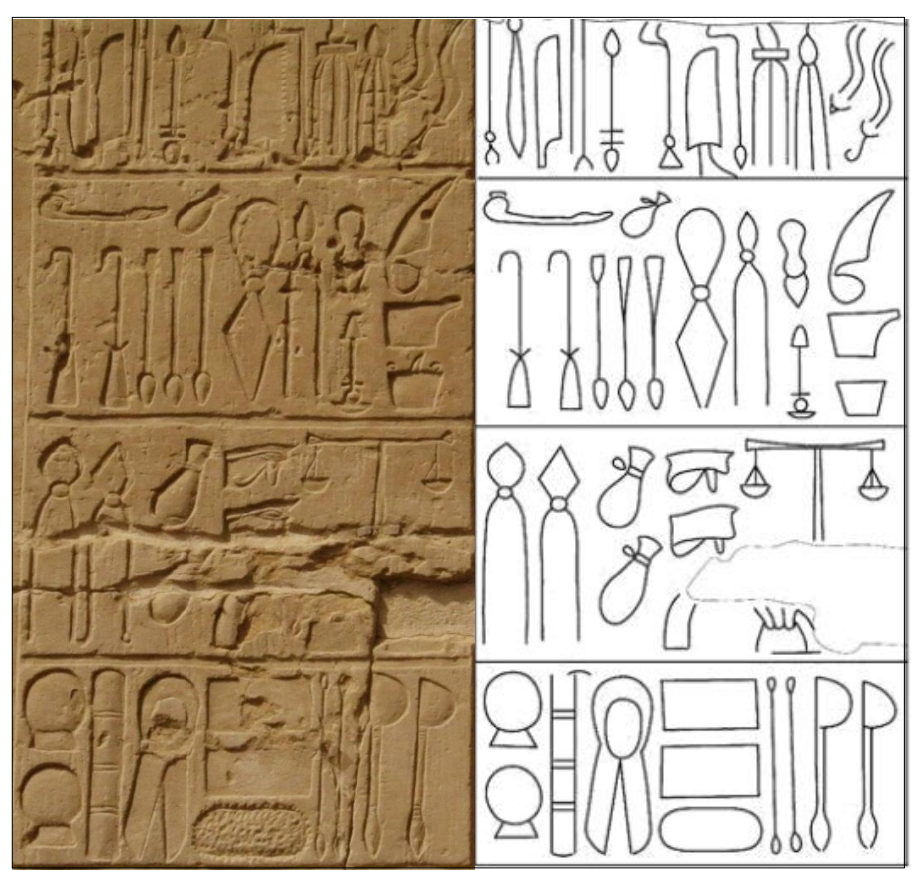

Figure (2) Shows the medical instruments depicted on the enclosure wall of the temple of Kom Ombo (after http://upload.wikimedia.org/wikipedia/commons/3/32/SFEC-KOM_OMBO-2010-05-076_\%282\%29.JPG; drawing after: Strouhal, Vachala, and Vymazalova, The Medicine of the Ancient Egyptians, 86, Fig. 21)

\section{The Architectural evidences}

The sanatorium, attached to the Egyptian temple, was the very ancient equivalent of a medical or magical clinic, with hospital attributes, where the sick or injured could come to seek healing from the gods and perhaps, the wisdom of the priests of the temple. Unfortunately, few such structures remain, though there are rooms at some temples that are thought to perhaps be sanatoria including one at Hatshepsut's temple at Deir el-Bahari [21], one in the temple of Imhotep on Elephantine [46]. The only remaining example of such sanatoria that once had their presence in large temples is that one at Denderah. It has retained almost all its elements and basically built for medical purposes [47]. Within the precinct of the Hathor temple complex at Dendera, towards the central temple, there is a maze of mud-brick buildings, sometimes called stores. Fortunately, the inscriptions incised on a pedestal in situ can clarify the nature of this complex as a sanatorium, fig. (3). The sanatorium of Denderah consists of a central courtyard surrounded by four axial corridors contain many cubicles that are basins or bathtubs. These bathtubs are not intended for ablutions but they were part of a therapeutic system making use of holy water flowed from statues placed on pedestals then diverted to a small tank. From there it drew to places in the different pools for immersing parts of the body such as legs, feet or the whole body. Rooms arranged around the central corridor provided an appropriate site for the incubation treatment [48]. At the central courtyard of the sanatorium, statues of the goddess were placed; these were inscribed with magical texts. Priests would pour libations, water from the sacred lake, on these statues. The already sacred water was then thought to be imbued with extra healing power from the statues, and was given to the sick to drink or bath [1]. None of these healing statues remains at Dendera, but there is a text on a block of stone in one of the cells of the sanatorium [48]. A similar stela was found in Tell Atrib, in Lower Egypt, in a complex of Ptolemaic baths [49]. One such healing statue in black granite was also found in Tell Atrib, 
belonging to a man called Djedhor. At the base of it is a small basin, where the poured water was collected after being poured over the statue and its magical texts. The influence of the texts would be absorbed into the water and their effects obtained by drinking the water [1]. These healing statues were placed in temples since the New Kingdom [50,51] that might signalize the existence of similar sanatoria attached to the New Kingdom temples. The existence of such healing statue and stela in Tell Atrib may indicate that the complex of Ptolemaic baths has functioned as a sanatorium, comparable to the well-known sanatorium of Dendera [49]. The sanatorium at Dendera was probably a very popular place, with people coming from afar to take advantage of the healing powers of Hathor, a deity known for her compassion [47]. Perhaps the majority of visitors were women, as she was also the patron deity for women especially. At these sanatoria, patients came to be immersed wholly or partially in sacred water and to practice incubation. They spend the night in the hope of receiving a healing, or visionary dream, which was interpreted by the priests. It was hoped the dream would hold a message, or a recipe, from the gods about how healing could be fulfilled. Doubtless, in many cases, a cure was affected through the awakening of an expecta- tion of cure in the sleeper himself. Thus, the temple sleep was used as a form of faith healing. Suggestions received during dreams that a cure had been affected were found to have achieved their purpose when the sufferer awoke. The more emotional and highly strung the patient, the greater the probability of cure [52]. Although the practice of incubation is not proven before the Late Period, there is an earlier indication to such practice. On the stela of Qenher-khepeshef, of the twentieth dynasty, found at Deir el-Medina and kept in the British Museum [53], he mentioned, "I have spent the night in this forecourt. I have drunk the water. My body has spent the night in the shadow of your face" [54]. The sanatorium at Dendera existed at least since the first stages of Ptolemaic era. However, it could be that the hydraulic system in its last state still visible today only dates from Roman times [48]. This Dendera sanatorium seems to reflect the divine healing practiced in ancient Greece, which was contemporary. Greek experience with incubation is well documented, and water plays a major part of the process [1]. Most likely, the Sanatorium at Dendera, and other temples were connected with the House of Life attached to the temples, the place where sacred texts and books were kept and the study of both medicine and other disciplines was practiced.

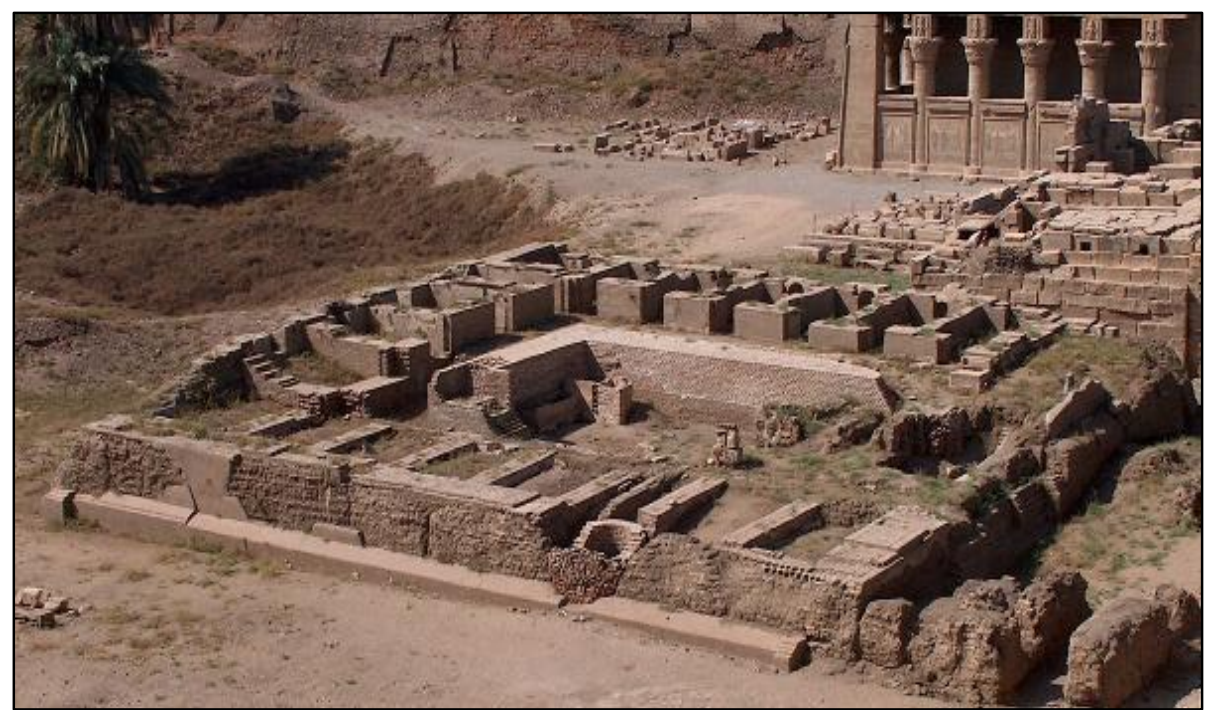

Figure (3) Shows the sanatorium within the precinct of the Hathor temple complex at Dendera (after: http://looklex.com/egypt/dendera09.htm) 


\section{Discussion and Commentary}

Such travels of patients to those healing centers, which proved through textual, pictorial, and archaeological evidences, could be compared to the modern concept of tourism. The components of tourism, in general, and the type of medical tourism, in particular, could be applied on similar activities practiced by patients in ancient Egypt. The United Nation World Travel Organization defines tourism as "the activities of persons travelling to and staying in places outside their usual environment for not more than one consecutive year for leisure, business and other purposes not related to the exercise of an activity remunerated from within the place visited" [55]. It could be deduced, through this definition, that there are many components of tourism. The most essential components are three: transport, locale and accommodation [56]. One of the types of tourism is medical tourism which simply could be defined as "travel of people to a certain destination for the purpose of obtaining medical treatment in that destination", although there are a range of other definitions vary from the minimalist to the most detailed [57]. In the context of patient travel in ancient Egypt, the three components could be applied as the following: Transport is very essential and necessary for tourism, as a tourist has to travel in order to get his destination [58]. The patient who visited the medical centers in Egyptian temples had to travel from his place of origin. Although there are no clear mention of means of transport used by patient to visit physician, no doubt there was patient movement and travel. There were two types of travel related to the work of the Egyptian physician; the first is the patient travel to the clinic of doctor in his medical centers, while the second is the travel of the doctor himself to the place of the patient. These travels are documented through textual, pictorial and architectural evidences. Although the second type, travels by doctors to the patients, cannot be considered tourism as it actually work, the first type, travel by patients to doctors, is, doubtless, tourism. It includes the two main classifications of tourism according to the place of origin of the tourists, the domestic tourism represented by the travels of the Egyptian patients to the healing centers, and the inbound tourism reflected by the travels of foreigner patients from their homelands to the Egyptian doctors in their clinics. It is proved that travel to the healing centers in Egyptian temples was not only practiced by Egyptian patients but also there are some foreigner patients who came to Egypt for the same purpose. This inbound tourism is well documented through ages. Although its Graeco-roman documentations are more numerous than Pharaonic evidences. Locale is another basic component of tourism; it might include the destination and what it offers to the traveler. It is considered as the most important basic component without its existence no tourism exists [59]. The healing centers attached to the Egyptian temples played the role of the locale and its attractions. Accommodation is the third basic component of tourism. It is essential for the traveler, after having reached his destination, for providing food, sleep and rest [56]. Ancient Egyptian sanatoria played the role of accommodation component in such ancient medical tourism. Although nothing is known about providing food in those Egyptian sanatoria, providing sleep and rest is not a matter of doubt.

\section{Conclusion}

There is no doubt that one at least of two different types of attached building related to medicine existed in some of the ancient Egyptian temple, the house of life and the sanatorium. The house of life connected in somehow to teaching medicine, such matter was certified through many evidences. It also could to be functioned as medical centers according to some hints in Egyptian sources. The sanatorium had no function other than a place for practicing incubation hoping for cure. These medical centers in Egyptian temples were the places towards which the patient travelled seeking for healing. No doubt that these patients moved from their usual environment (transport) to another place (locale) in which they spent 
period of time (accommodation). Thus, such travel could be explained within the modern concept of tourism as a type of tourism. It contains the three basic components of modern tourism, travel, locale and accommodation, this lead to conclude that such visits to the medical centers in ancient Egypt are the prototype of the present day medical tourism.

\section{References}

[1] Nunn, J., (1996). Ancient Egyptian medicine, British Museum Press, London.

[2] Strouhal, E., Vachala, B. \& Vymazalová, H. (2014). The medicine of the ancient Egyptians 1: surgery, gynecology, obstetrics, and pediatrics, AUC press, Cairo.

[3] Homer, (2003). The odyssey, Translated by Rieu, E., Penguin Classics, London.

[4] Herodotus, (1890). The history. Vol. II, Translated by Macaulay, G., Macmillan and Company, London.

[5] Habachi, L. and P. Ghalioungui (1971). The "House of Life" of Bubastis, Chronique d'Égypte, Vol. 46 (91), pp: 59-71.

[6] von Känel, F., (1984). Les prêtres-ouâb de Sekhmetet les conjurateurs de Serkhet, Presses Universitaires de France, Paris.

[7] Rößler-Köhler, U., (1985). Zur Text komposition der naophoren statue des Udjahorresnet / Vatikan Inv.-Nr. 196, Göttinger Miszellen, Vol. 85, pp: 43-54.

[8] Gardiner, A., (1938). The house of life, JEA, Vol. 24 (2), pp: 157-179.

[9] Jelínková-Reymond, E., (1956). Quelques recherches sur les réformes d'Amasis, ASAE, Vol. 54, pp: 251-287.

[10] Bryan, C., (1930). The papyrus Ebers, Geoffrey Bles, London.

[11] Reisner, G., (1905). The Hearst medical papyrus, J.C. Hinrichs, Leipzig.

[12] Junker, H., (1953). Gîza XI. der Friedhofsüdlich derCheopspyramide, Österreichische Akademie der Wissenschaften, Vienna.

[13] Newberry, P., (1895). El-Bersheh, II, Egypt Exploration Fund, London.

[14] Botti, G., (1954). La raccolta di antichitàegizie Wilson-Barker e I papyri geroglific ifunerari Bonzanidel Museoegizio di Firenze, Aegyptus, Vol. 34, pp: 63-75.

[15] Pendlebury, J., (1951). The city of Akhenaten, Part III, Egypt Exploration Society, London.
[16] Lichtheim, M., (1980). Ancient Egyptian literature: A book of readings, Vol. III, University of California Press, Berkeley.

[17] Habachi, L. \& P. Ghalioungui (1969). Notes on nine physicians of Pharaonic Egypt of whom five hitherto unknown, Bulletin de l' Institut Égyptien, Vol. 51, pp: 15-23.

[18] van de Walle, B. \& de Meulenaere, H., (1973). Compléments à la prosopographie médicale, Revue d'égyptologie, Vol. 25, pp: 58-83.

[19] Petrie, F., (1924). The palace titles, Ancient Egypt, Vol. IV, pp: 109-122.

[20] Marciniak, M., (1981). Un texteinédit de Deir el-Bahari, BIFAO, Vol. 81, pp: 283-291.

[21] Milne, J., (1914). The sanatorium of Dêrel-Bahri, JEA,Vol. 1, pp: 96-98.

[22] Philips, A., (1986). Observation on the alleged new kingdom sanatorium at Deir elBahari, Göttinger Miszellen, Vol. 89, pp: 77-83.

[23] Peden, A., (2001). The graffiti of Pharaonic Egypt, Brill, Leiden.

[24] Hurry, J., (1926). Imhotep the vizier and physician of king Zoser and afterwards the Egyptian god of medicine, Oxford Univ. Press, Oxford.

[25] Ghalioungui, P., (1983). The physicians of Pharaonic Egypt, Al-Ahram Center for Scientific Translations, Deutsches Archäologisches Institut, Abteilung Kairo 10.

[26] Zaccagnini, C., (1983). Patterns of mobility among ancient near eastern craftsmen, JNES, Vol. 42, pp: 245-264.

[27] Moran, W., (1992). The Amarna letters, Johns Hopkins Univ. Press, Baltimore.

[28] Edel, E., (1976). Ägyptische ärzte und ägyptische medizin am hethitischen Königshof. Neue Funde von Keilschriftbriefen Ramses' II. aus Boğazköy, Westdeutscher Verlag, Opladen.

[29] Kitchen, K., (1996). Ramesside Inscriptions. Translated \& Annotated, Vol. II: Ramesses 
II, Royal Inscriptions, Wiley-Blackwell, Oxford.

[30] Lloyd, A., (1982). The inscription of Udjahorresnet, A Collaborator's Testament, JEA, Vol. 68, pp: 166-180.

[31] David, A., (2003). Handbook to life in ancient Egypt, Facts on File Inc, NY.

[32] Porter, B. \& Moss, R. (1994). Topographical bibliography of ancient Egyptian hieroglyphic texts, reliefs and paintings I: The Theban necropolis, Part I: Private Tombs. Revised ed., Oxford Univ. Press, Oxford.

[33] Engelmann-von Carnap, B., (1999). Die Struktur des Thebanischen Beamtenfriedhofsin der ersten Hälfte der 18. Dynastie: Analyse von Position, Grundrißgestaltung und Bildprogramm der Gräber, Abhandlungen des Deutschen Archäologischen Instituts Kairo 15, Achet, Berlin.

[34] Shirley, J., (2007). The life and career of Nebamun, the physician of the king in Thebes, in: Hawass, Z. \& Richards, J. (eds.), The Art and Archaeology of Ancient Egypt: Essays in Honor of David B. O'Connor, Supplément aux Annales du Service des Antiquités de l'Égypte, Cahier 36, Vol. II, pp: 381-401.

[35] Habrich, Ch., Kolta, K. \& Schoske, S. (1985). Ein Leib für Leben und Ewigkeit: Medizinimalten Ägypten, Kataloge des Deutschen Medizinhistorischen Museums Ingolstadt 7, Deutschen Medizinhistorischen Museums, Ingolstadt.

[36] Davies, N. \& De G., (1933). The tomb of Menkheperrasoneb, Amenmose, and another, Theban tomb, Series 5, Egypt Exploration Society, London.

[37] Dziobek, E., (1994). Die gräber des vezirs User-Amun Theben Nr. 61 und 131, AV 84 , Verlag Philipp von Zabern, Mainz am Rhein.

[38] Killen, G., (1980). Ancient Egyptian furniture, Vol.1. 4000-1300 B.C, Aris \& Phillips, Warminster.

[39] Fischer, H., (1975). An elusive shape within the fisted hands of Egyptian statues, Metropolitan Museum Journal, Vol. 10, pp: 9-21.
[40] Strudwick, N., (2001). Problems of recording and publication of paintings in private tombs of Thebes, in: Davies V. (ed.), Colour and Painting in Ancient Egypt, British Museum Press, London, pp: 126-140.

[41] Wachsmann, S., (1987). Aegeans in the Theban tombs, Orientalia Lovaniensia Analecta 20, Peeters, Leuven.

[42] Panagiotopoulos, D., (2006). Foreigners in Egypt in the time of Hatshepsut and Thutmose III, in: O'Connor D. \& Cline, E. (eds.), Thutmose III: A new biography, University of Michigan Press, Ann Arbor, pp: 370-412.

[43] Murnane, W., (2000). Imperial Egypt and the limits of power, in: Cohen, R. \& Westbrook, R. (eds.), Amarna Diplomacy: The Beginnings of International Relations, Johns Hopkins University Press, Baltimore, pp: 101-111.

[44] Davies, N. De, G., (1927). Two Ramesside tombs at Thebes, Metropolitan Museum of Art, NY.

[45] Wesrendorf, W., (1999). Handbuch der altägyptischen Medizin. Brill, Leiden.

[46] Laskowska-Kusztal, E., (1995). Imhotep d'Elephantine, in: Schoske, S. (ed.), Akten des vierten Internationalen Ägyptologen Kongresses München 1985. Band 3: Linguistik, Philologie, Religion, 281-287, Buske, Hamburg, pp: 281-287.

[47] Wilkinson, R., (2000). The complete temples of ancient Egypt, Thames \& Hudson, NY.

[48] Daumas, F, (1957). Le sanatorium de Dendara, BIFAO, Vol. 56, pp: 35-57.

[49] Laskowska-Kusztal, E., (1995). La stèled' Horus sur les crocodilesd' Athribis, Études et Travaux, Vol. 17, pp: 85-93.

[50] Kákosy, L., (1987). Some problems of the magical healing statues, In: Roccati, A. \& Siliotti, A. (eds.), La magia in Egittoai tempi deifaraoni: atti, convegnointernazionale di studi, Milano, Verona, pp: 171-186.

[51] Kákosy, L., (1995). Heilstatuen in den Tempeln, in: Kurth, D. (ed.), 3. Ägyptologische Tempeltagung, Hamburg, Systeme und Programme der ägyptischen Tempeldekoration, Harrassowitz, Wiesbaden, pp: 91-98. 
[52] Meier, C., (2009). Healing dream and ritual: Ancient incubation and modern psychotherapy, Daimon Verlag, Einsiedeln.

[53] Bierbrier, M., (1982). The tomb-builders of the pharaohs, British Museum Publication, London.

[54] Quirke, S., (2014). Exploring religion in ancient Egypt, John Wiley \& Sons, West Sussex.

[55] Becken, S. \& Hay, J. (2007). Tourism and climate changes risks and opportunities, Multilingual Matters, Toronto.
[56] Jayapalan, N., (2001). An introduction to tourism, Atlantic Publishers and Distributors, New Delhi.

[57] Connell, J., (2011). Medical tourism, CABI, Wallingford, Oxfordshire.

[58] Bhatia, A., (2007). The business of tourism: Concepts and strategies, Sterling Publishers Pvt, New Delhi.

[59] Raj, K., (2002). Modern dictionary of tourism, Sarup \& Sons, New Delhi. 